\title{
Penatalaksanaan Syok Sepsis dengan Penyulit Cedera Ginjal Akut pada Pasien Peritonitis Sekunder
}

\author{
Masriani, Haizah Nurdin, Faisal Muchtar \\ Departemen Anestesiologi dan Terapi Intensif \\ Fakultas Kedokteran Universitas Hasanuddin-RSUP Wahidin Sudirohusodo Makassar
}

\begin{abstract}
Abstrak
Peritonitis akibat infeksi intraabdominal, khususnya peritonitis sekunder merupakan salah satu penyebab syok sepsis dengan tingkat morbiditas dan mortalitas yang tinggi. Perkembangan dalam pemahaman fisiologi, pemantauan, dan tunjangan sistem kardiopulmonal, serta penggunaan obat-obat baru secara rasional membuat mortalitas stabil pada kisaran 30\%. Kasus ini mengenai seorang pasien perempuan usia 67 tahun masuk rumah sakit dengan diagnosis peritonitis generalisata karena suspek perforasi Hollow viscous. Setelah menjalani operasi laparatomi untuk source control, pasien dirawat di ICU selama 5 hari. Selama perawatan pasien mengalami edema paru, sepsis, anemia, hipokalemia, hipoalbuminemia, serta acute kidney injury (AKI). Pada pasien dilakukan tindakan ventilasi mekanik selama 4 hari yang diiringi dengan pemantauan analisis gas darah arteri dan furosemid untuk tata laksana edema paru dan fluid overload. Resusitasi dan pemeliharaan cairan sambil memantau hemodinamik konvensional dan melalui ICON, balance kumulatif, fluid overload, tekanan vena sentral, serta urine output. Terapi antimikrob diberikan berdasar atas pedoman terapi infeksi intraabdominal dan antibiogram ICU rumah sakit. Kondisi perfusi dipantau dengan kadar laktat dan SCV02. Respons antibiotik dan perbaikan sepsis dipantau dengan pemeriksaan prokalsitonin dan leukosit. Perbaikan AKI dipantau dengan produksi urine serta kadar ureum dan kreatinin. Penatalaksanaan peritonitis sekunder dengan komplikasi sepsis dengan penyulit AKI telah berhasil dilakukan di ICU. Peritonitis sekunder memiliki tingkat mortalitas yang cukup tinggi, namun dengan source control yang adekuat dan manajemen di ICU yang agresif maka diperoleh hasil yang baik seperti pada kasus ini.
\end{abstract}

Kata kunci: Cedera ginjal akut, peritonitis, peritonitis sekunder, syok sepsis

\section{Management of Septic Shock with Acute Renal Failure Complications in Secondary Peritonitis Patients}

\begin{abstract}
Peritonitis due to intraabdominal infection, especially secondary peritonitis is one of the major causes of septic shock with high morbidity and mortality. Developments in understanding the physiology, monitoring and supportive therapy for cardiopulmonary system and rational use of new drugs, make mortality stable at around 30\%. A 67-year-old female patient was hospitalized with generalized peritonitis due to suspected Hollow Viscous perforation. After undergoing laparotomy for source control, the patient was treated in the ICU for five days. During treatment, the patient experiences pulmonary edema, sepsis, anemia, hypokalaemia, and hypoalbuminemia, and acute kidney injury (AKI). The patient received mechanical ventilation intervention for four days accompanied by monitoring of arterial blood gas analysis and furosemide administration for pulmonary edema and fluid overload management. Fluid resuscitation and maintenance are monitored by conventional hemodynamic monitoring and through ICON, and by cumulative balance calculation, fluid overload calculation, central venous pressure, and urine output. Antimicrobial therapy is given based on guidelines for intraabdominal infection therapy and antibiogram at the hospital ICU. The condition of perfusion is monitored by examination of lactate and SCVO2 levels. Antibiotic response and improvement in sepsis are monitored by examination of procalcitonin and leukocytes. AKI improvement is monitored by urine production, and urea and creatinine levels. Management of secondary peritonitis with complications of sepsis and AKI has been successfully carried out in the ICU. Secondary peritonitis has a fairly high mortality rate, but with adequate source control and aggressive management in the ICU, good results are obtained as in this case.
\end{abstract}

Keywords: Acute kidney injury, peritonitis, sepsis shock, secondary peritonitis, shock

Korespondensi: Masriani, dr., SpAn. M. Kes, Bagian Ilmu Anestesi, Perawatan Intensif, dan Manajemen Nyeri Fakultas Kedokteran Universitas Hasanuddin, Jalan Perintis Kemerdekaan KM 11 Tamanlarea Kota Makassar, tlpn 0411-582583, Email masrie2212@gmail.com 


\section{Pendahuluan}

Peritonitis adalah inflamasi terlokalisasi atau generalisata di dalam kavum peritonium yang umumnya disebabkan oleh bakteri atau jamur, namun dapat juga disebabkan oleh zat noninfeksi seperti kandungan gaster atau isi empedu. Peritonitis akibat infeksi diklasifikasikan atas primer, sekunder, atau tersier. Peritonitis ini diklasifikasikan berdasar atas integritas anatomi kavum abdominal. ${ }^{1}$

Sepsis memengaruhi 750.000 pasien setiap tahun di Amerika Serikat dan merupakan penyebab utama kematian pada pasien sakit kritis. Sebanyak 210.000 orang meninggal setiap tahun karena sepsis dan sekitar 15\% pasien sepsis menjadi syok sepsis. Sekitar 10\% akhirnya masuk ICU dengan angka kematian lebih dari 50\%. ${ }^{1}$ Syok septik adalah respons serius terhadap infeksi yang melibatkan sirkulasi dan kelainan metabolik seluler, hal ini memiliki efek substansial pada morbiditas dan mortalitas. Pedoman dari surviving sepsis campaign (SSC) menyebabkan penurunan kejadian sepsis, namun syok sepsis masih menyumbangkan $62 \%$ kasus syok dengan angka kematian di rumah sakit lebih besar dari 40\%. Intensive Care Unit (ICU) bedah, infeksi intraabdominal adalah penyebab sepsis yang paling umum dengan tingkat kematian 10,5\% di seluruh dunia. Mortalitas terkait syok sepsis menurun, namun laju disfungsi organ tetap tinggi. Cedera ginjal akut (acute kidney injury/ AKI) adalah salah satu komplikasi sepsis paling sering yang membahayakan 30-40\% pasien di ICU. Lebih dari $45 \%$ pasien dengan syok sepsis menderita AKI dan semuanya memiliki luaran yang buruk, termasuk lama rawat ICU dan rumah sakit, gagal ginjal kronik, penyakit ginjal stadium akhir, dan peningkatan mortalitas. $^{2}$

Sepsis terkait cedera ginjal akut (S-AKI) adalah komplikasi yang sering pada pasien sakit kritis. Pengenalan dini sangat penting untuk memberi pengobatan yang mendukung dan membatasi perkembangan lebih lanjut. Kriteria diagnostik saat ini membatasi deteksi dini, namun biomarker baru gangguan ginjal dan kerusakannya telah ada. Penelitian baru menunjukkan disfungsi mikrovaskular, inflamasi, dan gangguan metabolik menjadi mekanisme fundamental terjadi S-AKI. ${ }^{3}$

Meskipun terapi antibiotik telah berkembang signifikan dalam tata laksana penyakit yang mengancam nyawa, namun kematian akibat infeksi di Amerika Serikat (AS) dan di seluruh dunia masih banyak dan peritonitis akibat infensi intraabdominal (IAI) termasuk dalam penyakit ini. Mortalitas infeksi intra-peritonium pada awal tahun 1900an mendekati $90 \%$. Kondisi ini umumnya diterapi tanpa operasi sampai Kishner memperkenalkan prinsip dasar pembedahan pada infeksi intraabdominal. Pada kisaran tahun 1930-an, mortalitas telah berkurang hingga 50\%. Beberapa antibiotik baru saat itu maka mortalitas menurun perlahan. Penggunaan cephalosphorin pada awal tahun 1970-an menurunkan mortalitas hingga 30-40\%. Perkembangan dalam pemahaman fisiologi, pemantauan, tunjangan sistem kardiopulmonal, serta penggunaan obat-obat baru secara rasional membuat mortalitas stabil pada kisaran $30 \%{ }^{4}$

\section{Laporan Kasus}

Pasien perempuan (Ny. RA) usia 67 tahun, berat badan (BB) $50 \mathrm{~kg}$ masuk ke Instalasi Rawat Darurat (IRD) Rumah Sakit Wahidin Sudirohusodo (RSWS) dari rujukan RSUD dengan diagnosis peritonitis generalisata e.c. suspek perforasi hollow viscous. Anamnesis didapatkan bahwa pasien mengeluh nyeri perut hebat sejak 2 minggu terakhir. Nyeri terasa tembus sampai ke pinggang dan punggung bawah. Mual dan muntah sering dialami. Riwayat penyakit lain disangkal. Riwayat dirawat di rumah sakit daerah selama 7 hari.

Pada pemeriksaan fisis ditemukan status jalan napas paten, pernapasan spontan, frekuensi napas $24 \mathrm{x} /$ menit, tekanan darah (TD) $72 / 52 \mathrm{mmHg}$, laju jantung $112 \mathrm{x} /$ menit, Glasgow coma scale (GCS) 15 (E4M6V5), dan suhu $36,5^{\circ} \mathrm{C}$. Abdomen distended dengan peristaltik meningkat dan ada edema pretibial. Pemeriksaan penunjang diperoleh temuan 


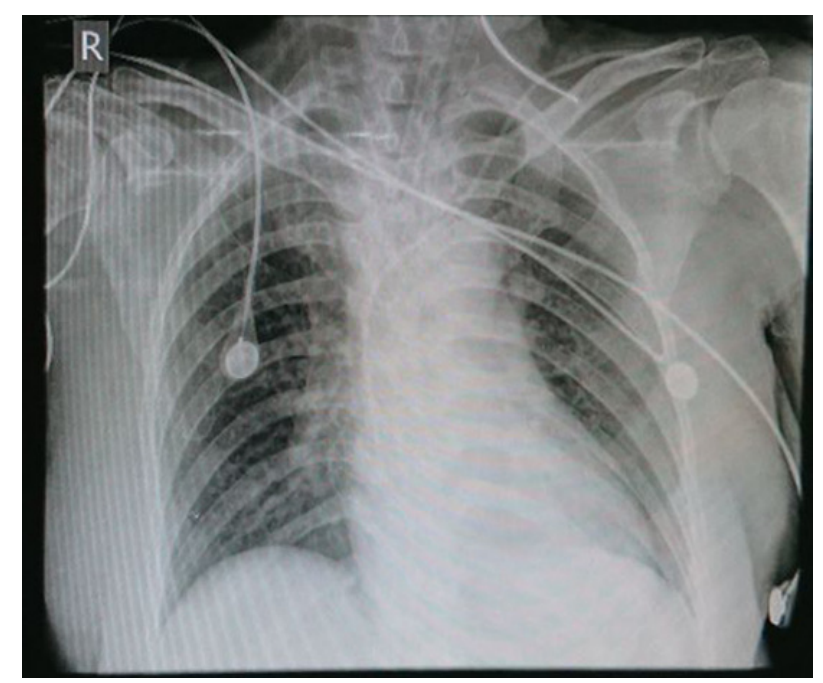

Gambar 1 Ronsen toraks Tanggal 23 Februari 2020: Pneumoperitoneum dan Dilatasi Aorta, Edema Paru Minimal

Sumber: Dokumentasi pribadi

anemia $\mathrm{Hb}$ 9,0 g/dL, leukositosis (leukosit 32.640/mm3), trombositosis (Plt 685.000/ $\mathrm{mm}^{3}$ ), hipokalemia (kalium 2,8 meq/L), dan hipoalbuminemia $(2,1 \mathrm{mg} / \mathrm{dL})$. Saat di IGD pasien menerima resusitasi cairan dengan cairan Ringer laktat (RL). Pasien menerima obat intravena dan antibiotik cefotaxim $1 \mathrm{~g}$. Produksi urine pasien selama di IGD berkisar $10 \mathrm{~mL} / \mathrm{jam}$.

Sekitar 3 jam setelah masuk rumah sakit pasien menjalani operasi laparatomi (open midline) selama 6 jam dengan anestesi GETA. Selama operasi, perdarahan berkisar 350 cc

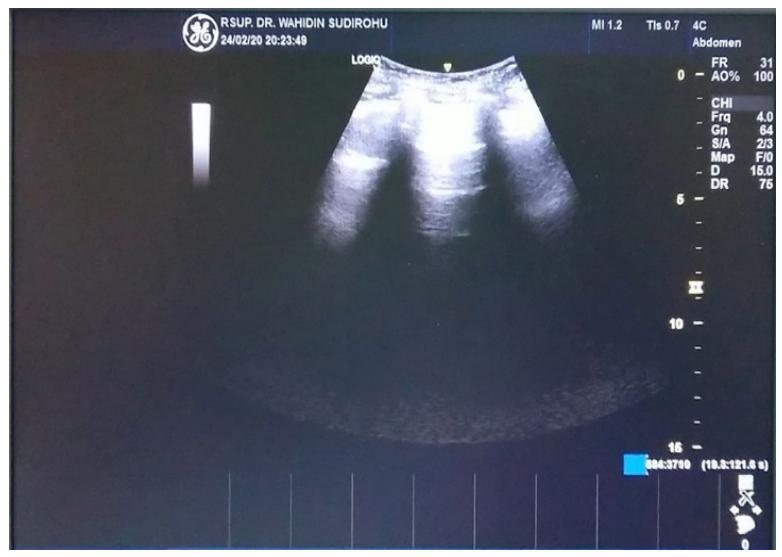

(a) dan produksi urine $100 \mathrm{cc}$. Pasien menerima cairan intravena kristaloid $2.500 \mathrm{cc}$, koloid $500 \mathrm{cc}$, transfusi whole blood $500 \mathrm{cc}$, serta diberikan asam traneksamat (TXA) 1 gram dengan dosis rumatan $500 \mathrm{mg} / 8$ jam. Tekanan darah sistole (TDS) intraoperatif berkisar 80-110 mmHg, tekanan darah diastole (TDD) 30-55 mmHg, dan HR 80-122x/menit dengan topangan norepinefrin $0,1 \mathrm{mcg} / \mathrm{kgBB} /$ menit dan dobutamin $0,5 \mathrm{mcg} / \mathrm{kgBB} /$ menit. Pasien tidak diekstubasi dan ditransfer ke ICU.

Pada pemeriksaan fisis pasien saat awal masuk di unit perawatan intensif ditemukan:

Gambar 2 (a) USG Paru: Tidak Ada Tanda-Tanda Edema Paru

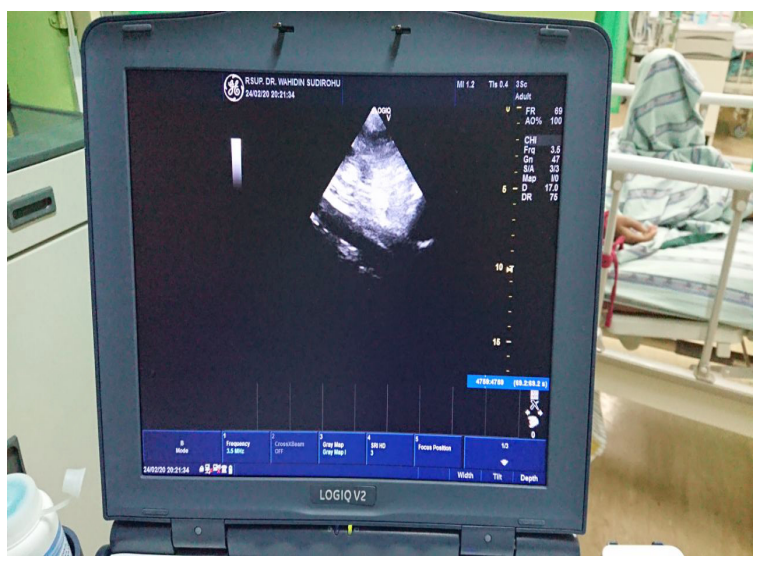

(b)

(b) IVC: Indeks Kollapsibilitas Vena Kava Inferior $<50 \%$

Sumber: Dokumentasi pribadi 
Tabel 1 Rangkuman Penilaian, Rencana, dan Tindakan Selama Hari Perawatan di ICU

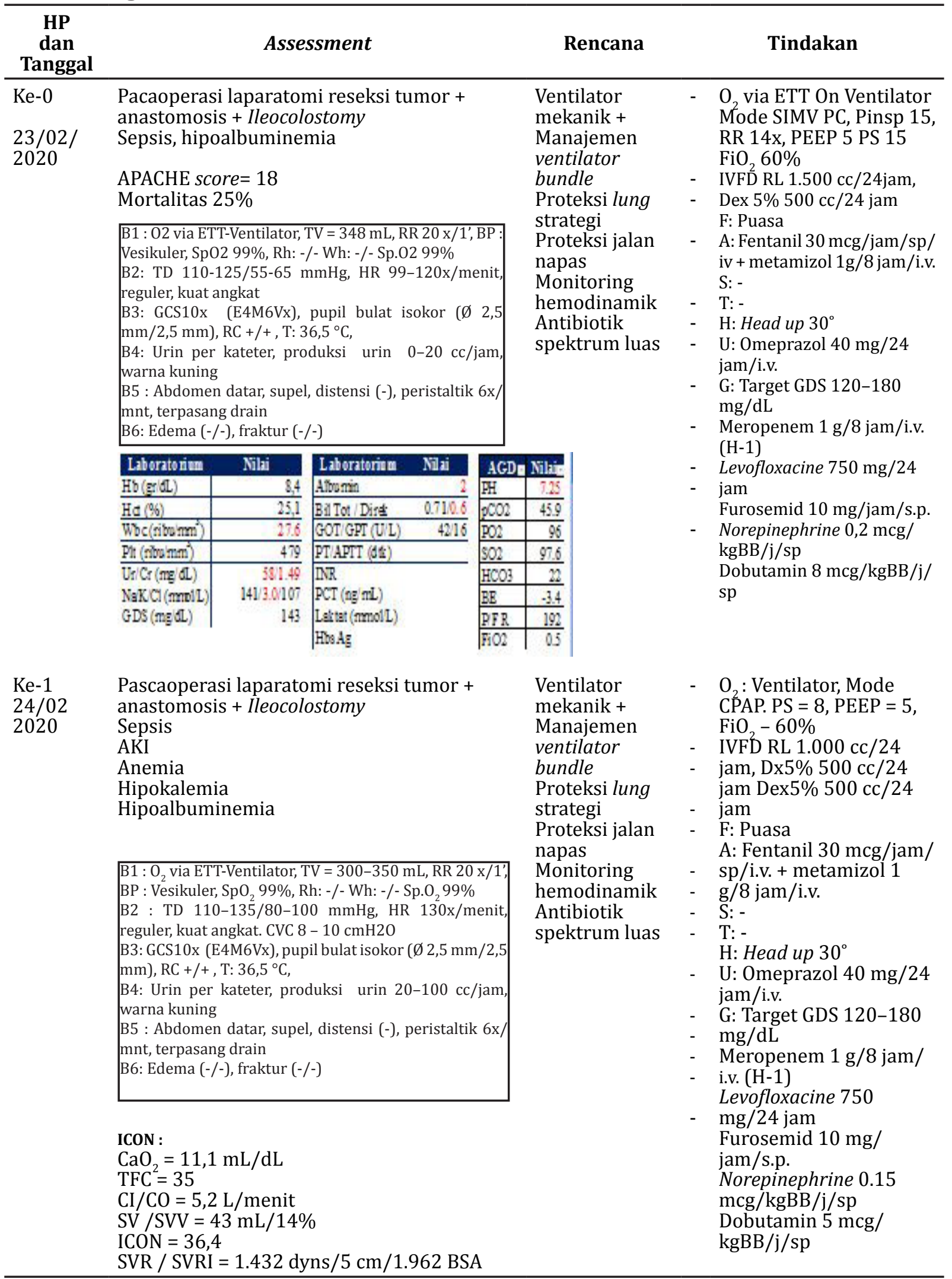




\begin{tabular}{|c|c|c|c|c|c|c|}
\hline $\begin{array}{l}\mathrm{Ke}-2 \\
25 / 02 \\
2020\end{array}$ & \multicolumn{4}{|c|}{ 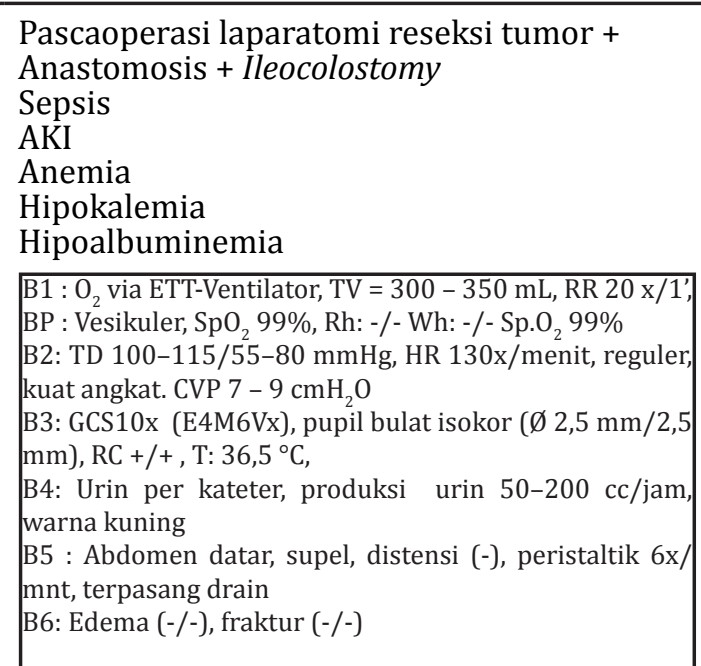 } & $\begin{array}{l}\text { Ventilator } \\
\text { mekanik + } \\
\text { Manajemen } \\
\text { ventilator } \\
\text { bundle } \\
\text { Proteksi lung } \\
\text { strategi } \\
\text { Proteksi jalan } \\
\text { napas } \\
\text { Monitoring } \\
\text { hemodinamik } \\
\text { Antibiotik } \\
\text { spektrum luas }\end{array}$ & 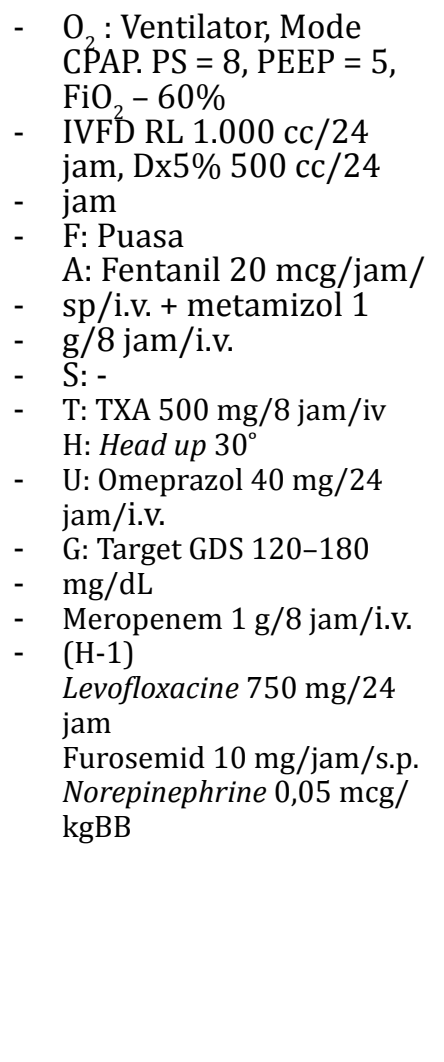 \\
\hline $\begin{array}{l}\mathrm{Ke}-3 \\
26 / 02 \\
2020\end{array}$ & \multicolumn{4}{|c|}{ 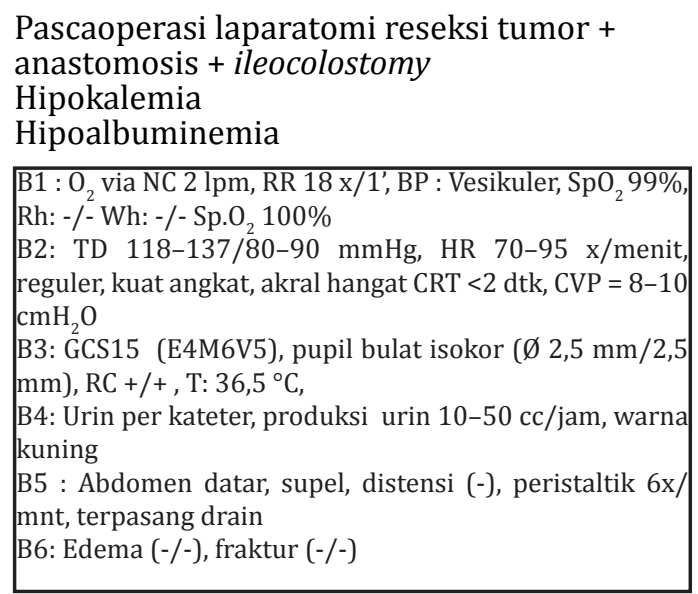 } & $\begin{array}{l}\text { Ventilator } \\
\text { mekanik + } \\
\text { Manajemen } \\
\text { ventilator } \\
\text { bundle } \\
\text { Proteksi lung } \\
\text { strategi } \\
\text { Proteksi jalan } \\
\text { napas } \\
\text { Monitoring } \\
\text { hemodinamik } \\
\text { Antibiotik } \\
\text { spektrum luas }\end{array}$ & 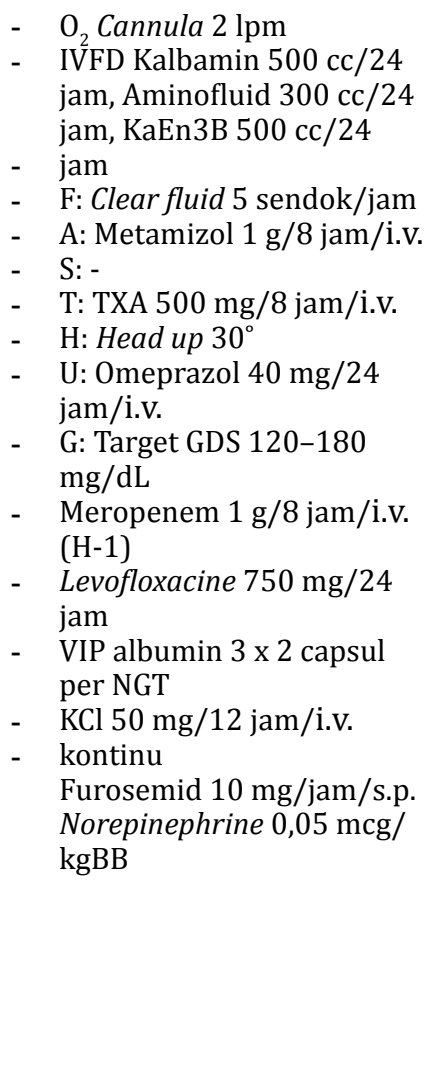 \\
\hline
\end{tabular}




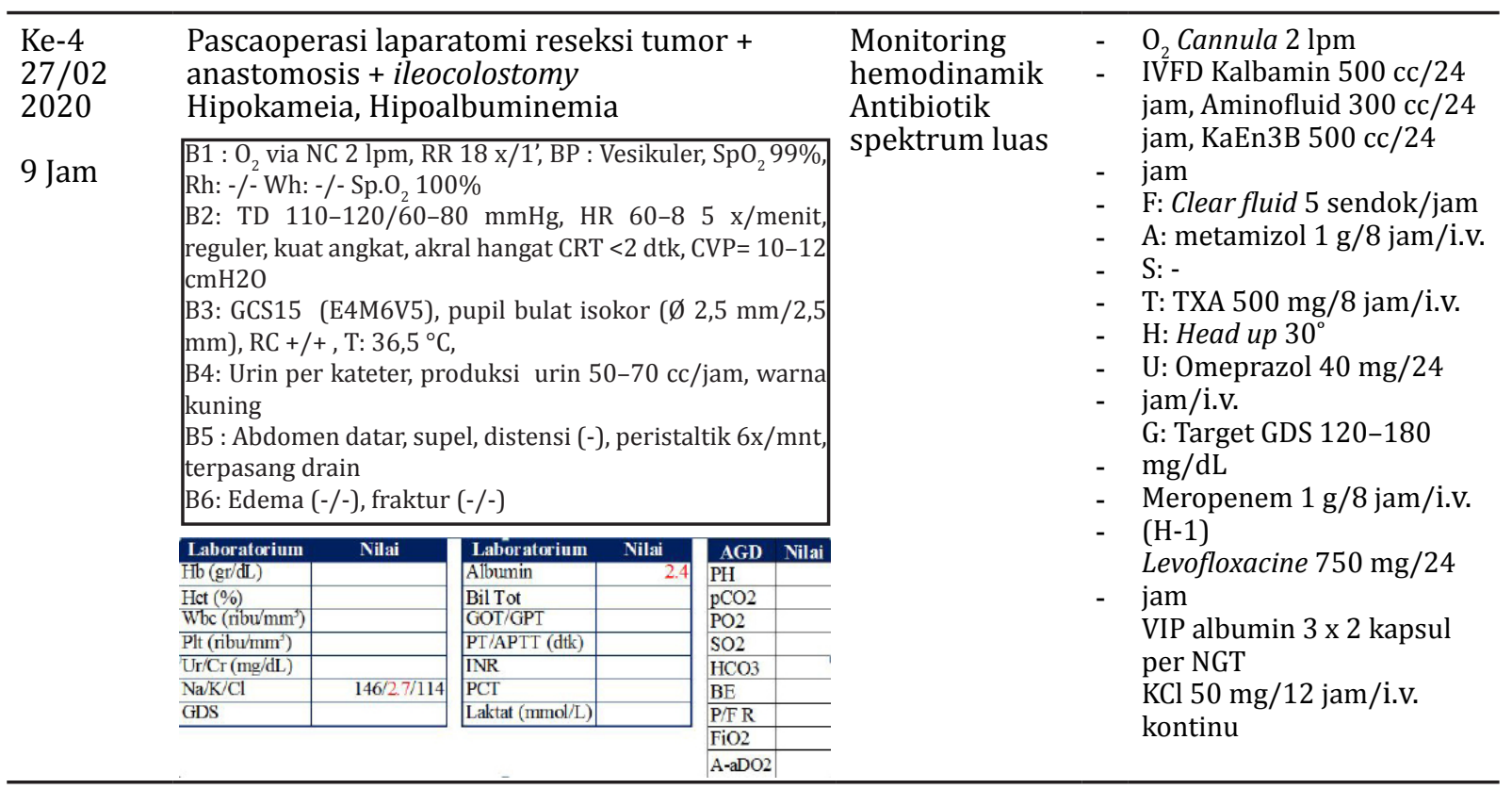

B1: $\mathrm{O}_{2}$ Via ETT-Jackson Rees 8 lpm, RR 12x menit, $\mathrm{SpO}_{2}$ 99\% Rh-/-, Wh-/-; B2: TD 85/42 mmHg (MAP 56); HR 67x/menit, reguler, kuat angkat, akral hangat, CRT $<2$ dtk; B3: GCS: tersedasi, pupil bulat isokor $(\varnothing 2,5$ $\mathrm{mm} / 2,5 \mathrm{~mm}$ ), $\mathrm{RC}+/+, \mathrm{T}: 36,8^{\circ} \mathrm{C}$;B4: Urin per kateter, produksi $10 \mathrm{cc} / \mathrm{jam}$, warna kuning; B5: abdomen datar, supel, ikut gerak napas, peristaltik $(+) 8 \mathrm{x} / \mathrm{mnt}$, terpasang drain; B6: edema (-/-) fraktur (-/-) sianosis (-/-). Keterangan: B1 adalah Breath (pernapasan), B2: Blood (jantung dan pembuluh darah), B3: Brain (susunan saraf pusat), B4: Bladder (saluran kemih), B5: Bowel (saluran cerna), dan B6 adalah Bone (tulang kerangka).

Pasien didiagnosis dengan pascaoperasi laparatomi eksplorasi, reseksi tumor, dan anastomosis serta ileocolostomy. Tindakan awal di ICU meliputi: ventilasi mekanik (VM) dengan strategi proteksi paru; Mode SiMV, RR 16x/menit, PEEP 5, PS 10. Dengan hasil luaran: TV 340-60 mL, $\mathrm{SpO}_{2} 98-99 \%$. $\mathrm{FiO}_{2}$ $100 \%$ dititrasi hingga 60\%. Resusitasi cairan dilanjutkan hingga 1.000 cc kristaloid (RL) untuk mencapai MAP $\geq 70 \mathrm{mmHg}$. Head up 3045 derajat, penghangat menggunakan selimut.

Pada pemeriksaan laboratorium diperoleh $\mathrm{Hb} 7,8 \mathrm{~g} / \mathrm{dL}$, leukosit $27.600 / \mathrm{mm}^{3}$, ureum 70 $\mathrm{mg} / \mathrm{dL}$, kreatinin 1,69 mg/dL, GDS $143 \mathrm{mg} /$
$\mathrm{dL}$, albumin $2 \mathrm{mg} / \mathrm{dL}$, dengan peningkatan prokalsitonin (PCT) hinggga 70,51 ng/mL dan peningkatan laktat hingga $3,1 \mathrm{mmol} / \mathrm{L}$. Hasil analisis gas darah diperoleh pH 7,25; $\mathrm{PCO}_{2} 45,9 \mathrm{mmHg}, \mathrm{PO}_{2} 96 \mathrm{mmHg}, \mathrm{SO}_{2}$ 97,6; $\mathrm{HCO}_{3}$ 22; $\mathrm{BE}-3,4 ; \mathrm{FiO}_{2}$ 0,5 dan P/F Ratio 192. Kesan asidosis metabolik tidak terkompensasi dengan gambaran perfusi jaringan berupa laktat darah 5,1 dan $\mathrm{ScvO}_{2} 68 \%$, produksi urine hanya berkisar $10 \mathrm{cc} / \mathrm{jam}$.

Selama di ICU, dari hasil pemeriksaan, ditemukan pasien sakit kritis dengan skor acute physiology and chronic health evaluation (APACHE) II, yaitu 18 dengan mortalitas 25\%. Perjalanan penyakit, rencana, serta tindakan yang dilakukan selama perawatan ICU telah dirangkum pada Tabel 1. Selama perawatan di ICU, pada pasien ini ditemukan gagal napas akut, asidosis metabolik, anemia, sepsis, serta gangguan keseimbangan elektrolit.

Pasien ini menerima ventilasi mekanik (VM) dengan strategi proteksi paru selama 2 hari melalui ETT (endotracheal tube). Pasien menerima VM mode SiMV selama 2 hari perawatan di ICU dan CPAP serta PS selama 1 hari di ICU. Tidal volume (dalam batas 300-380 cc) dan frekuensi napas ventilator diatur untuk mencapai minute volume (MV) yang dapat mempertahankan $\mathrm{PaCO}_{2}$ dalam 
batas 30-45 mmHg ( EtCO $_{2}$ lebih rendah). PEEP diberikan pada kisaran $5-10 \mathrm{cmH}_{2} \mathrm{O}$, PS pada kisaran 5-14. PIP ditargetkan maksimal $30 \mathrm{cmH}_{2} \mathrm{O}$ dan $\mathrm{P} / \mathrm{F}$ ditargetkan mencapai rasio $>300$. Pada saat masuk ICU dilakukan pemeriksaan radiologi dan dari gambaran foto rontgen toraks (chest X Ray) ditemukan pneumoperitoneum dan dilatatio aortae (Gambar 1).

Cairan pemeliharaan yang diberikan adalah Ringer laktat sekitar 500-1.500 cc. Cairan lainnya berasal dari enteral. Pencapaian CVP dalam kisaran 3-7 mmHg. Pada periode MAP $<70 \mathrm{mmHg}$ diberikan topangan norepinefrin $0,05 \mathrm{mcg} / \mathrm{kgBB} / \mathrm{menit}$ selama 4 hari disertai pemberian inotropik dobutamin $5 \mathrm{mcg} / \mathrm{kgBB}$ per menit selama 3 hari awal perawatan di ICU. Anemia $(\mathrm{Hb}<10 \mathrm{~g} / \mathrm{dL})$ dikoreksi pada pasien ini dengan PRC. Hipoalbuminemia $(<2,5 \mathrm{~g} / \mathrm{dL})$ dikoreksi dengan pemberian albumin 20\% 100 cc per 24 jam selama 3 hari perawatan. Pasien ini merima terapi meropenem $1 \mathrm{~g} / 8$ jam dan levofloxacyne 750 mg/24 HP-0 hingga HP terakhir. Furosemid $10 \mathrm{mg} / \mathrm{jam}$ kontinu yang dititrasi hingga intermitten setiap 8 jam diberikan selama 4 hari awal perawatan di ICU karena produksi urine yang cenderung berkisar 20-30 cc/kgBB. Pada pemeriksaan USG bedside 2 hari setelah perawatan, tidak diperoleh edema paru dan indeks kollaps IVC kurang dari 50\%.

Dari hasil pemeriksaan elektrolit ditemukan periode hipokalemia selam 3 hari perawatan. Pemeriksaan persentase fluid overload (FO) selama perawatan $<10 \%$ kecuali pada hari perawatan pertama dengan CVP sekitar 8-12 $\mathrm{mmHg}$ dan produksi urine $0 \mathrm{cc} / \mathrm{jam}$ hingga 300 cc per jam.

A : Analgesia pada HP-0 hingga HP-2 pasien menerima fentanil i.v. $20-50 \mathrm{mcg} / \mathrm{jam}$ dan metamizol $1 \mathrm{~g} / 8$ jam/i.v. Pada HP-3 hingga hari terakhir pasien hanya menerima metamizol 1 g/8 jam/i.v.

S: Sedasi pada hari pertama adalah midazolam 1-2 mg/jam

T : TXA $500 \mathrm{mg} / 8$ jam selama 3 hari

H : Head up $30^{\circ}$

U : Omeprazol $40 \mathrm{mg} / 24 \mathrm{jam}$

G : GDS ditergetkan $80-180 \mathrm{mg} / \mathrm{dL}$.

\section{Pembahasan}

Pada kasus ini, seorang pasien MRS dari rujukan RSUD lain dengan diagnosis peritonitis et causa perforasi hollow viscous. Peritonitis adalah inflamasi terlokalisasi atau generalisata di dalam kavum peritonium yang umumnya disebabkan oleh bakteri atau jamur, namun dapat juga disebabkan oleh zat noninfeksi seperti kandungan gaster atau isi empedu. Peritonitis akibat infeksi diklasifikasikan atas primer, sekunder, atau tersier. Peritonitis ini diklasifikasikan berdasar atas integritas anatomi kavum abdominal. ${ }^{1-5}$

Peritonitis primer berhubungan dengan organ kavum abdominal yang masih intak. Peritonitis ini juga dikenal sebagai peritonitis bakteri spontan dan diterapi tanpa intervensi bedah. Peritonitis ini tidak berhubungan langsung dengan proses intra-abdominal lain. Peritonitis ini mencakup peritonitis bakterial spontan (spontaneous bacterial peritonitis/ SBP) yang ditemukan pada pasien dengan asites akibat sirosis atau sindrom nefrotik dan peritonitis tuberkulosis.

Peritonitis sekunder merupakan infeksi kavitas peritoneum yang berasal dari usus atau pelvis dan mencakup peritonitis setelah perforasi hollow viscus, kebocoran anastomosis, nekrosis iskemik, atau cedera lain di dalam traktus gastroinstestinal. Peritonitis ini sering terjadi pada pasien bedah kritis. Iskemia intestinal dan nekrosis usus besar dapat disebabkan oleh berbagai macam proses termasuk keganasan, insufisiensi vaskular, volvulus, atau intususepsi. Ruptur abses pankreas, hepar, atau limpa, ruptur gallbladder/kantong empedu (jarang). Peritonitis abdominal bagian bawah juga dapat terjadi akibat infeksi ginekologik seperti salfingitis atau endometriosis.

Peritonitis tertier didefinisikan sebagai infeksi rekurren yang serius atau infeksi persisten pada intra-abdominal setelah kontrol peritonitis sekunder berhasil. Peritonitis ini juga dapat terjadi akibat dialisis peritoneal. ${ }^{6}$

Segera setelah kontak fisik pertama bakteri dengan peritoneum akan terjadi cedera pada sel-sel mesotelium yang disusul 
oleh aktivasi mediator inflamasi yang akan mengaktivasi respons imunologi seluler dan humoral. Respons awal peritoneum melawan bakteri ditandai oleh hiperemia dan eksudasi cairan meningkat bersamaan dengan fagosit di dalam kavum peritoneum. Pada tahap awal ini yang predominan adalah makrofag. Neutrofil muncul setelah 2-4 jam dan menjadi sel predominan dalam kavum peritoneum dalam 48-72 jam. Sel-sel tersebut melepaskan sitokin dalam jumlah besar seperti interleukin (IL)-1, IL-6, dan tumor necrosis factor (TNF), leukotriens, platelet activating factor, C3A dan C5A yang menginduksi inflamasi lokal yang lebih berat. Efek kombinasi mediator tersebut ditemukan selama respons inflamasi pada peritonitis. Sebagai konsekuensi inflamasi ini terjadi produksi fibrinogen pada fokus septik (Gambar 3). Akibat pembentukan fibrin yang cepat, tumpukan fibrin tersebut akan mengurangi dan menyumbat reabsorpsi cairan dari kavitas peritonium sehingga bakteri terperangkap di dalamnya. Fenomena inilah yang menyebabkan abses., ${ }^{3,5,7}$

Gangguan hemodinamik pada peritonitis memiliki beberapa dampak. Hipovolemia menurunkan volume ekstraseluler akibat pergeseran massif cairan ke dalam kavum peritonium dan menyebabkan penurunan cardiac index, peningkatan resistensi vaskular perifer, dan peningkatan konsumsi oksigen di perifer. Respons umum dan spesifik tubuh terhadap peritonitis dapat dilihat pada Gambar 4. Inilah alasan dilakukan resusitasi sebelum tindakan apapun seperti pada kasus ini. ${ }^{2-4,8-11}$

Setelah diresusitasi dilakukan laparatomi dan ditemukan tumor yang kemudian direseksi dan dilakukan anastomosis dan ileocolostomy selama 4 jam. Pascaoperasi pasien ditransfer ke ICU dalam keadaan terintubasi ETT oral. Pasien dirawat di ICU selama 4 hari dan mengalami komplikasi berupa hipotensi persisten dan anemia sehingga ditopang dengan vasopresor dan inotropik, AKI, hipokalemia, hipoalbuminemia. Pasien menerima tindakan ventilasi mekanik selama 2 hari. Fluid overload ditangani dengan furosemid. ${ }^{7,8}$
Syok sepsis merupakan komplikasi yang sering ditemukan pada peritonitis generalisata dengan akibat gagal organ ganda (MOF/ multiple organ failure) dan kadang kematian. Pada peritonitis sekunder, peritonitis akibat pascaoperasi umumnya dianggap lebih berat (mortalitas lebih tinggi) dibanding dengan peritonitis akuisita. Hal ini terjadi akibat supresi immun akibat pembedahan sebelumnya, hilangnya bersihan fisiologi normal dari peritoneum, benda asing dalam kavitas peritoneum (darah, cairan empedu), serta terapi empirik antibiotik awal yang tidak adekuat pada periode pascabedah peritonitis sehingga meningkatkan risiko resistensi patogen. ${ }^{1,5,7}$

Beberapa hari setelah peritonitis supuratif akut, tanda-tanda hipovolemia dan syok hipovolemik akan ditemukan. Ini terjadi akibat sekuestrasi cairan dari jaringan interstisiel ke kavitas peritoneum dan lumen usus. Hipotensi, takikardia, dan oligouria beserta peningkatan kadar nitrogen nonprotein dan kreatinin. Jika status sirkulasi tidak dikoreksi dan operasi darurat untuk peritonitis ditunda, pasien akan memburuk dengan cepat hingga meninggal. Pada pasien dengan perforasi usus ganda (multipel), atau pada mereka dengan operasi yang ditunda-tunda, atau tidak adekuat, eradikasi radikal sumber peritonitis akan sangat sulit dilakukan. Kematian akibat gagal organ ganda akan sangat mungkin pada pasien dengan kasus seperti ini. ${ }^{2,5,8}$

Manajemen peritonitis umumnya kompleks dan memerlukan pendekatan multidisipliner. Ahli bedah dan intensivis harus bekerja sama dengan praktisi penunjang nutrisi, terapi respirasi, penyakit infeksi, dan radiologi. Penggunaan protokol standar untuk resusitasi dan tunjangan hemodinamik/ventilator untuk fasilitasi seluruh tata laksana akan berdampak positif terhadap luaran pasien. Keseimbangan cairan sebaiknya dicapai dengan cepat melalui pergantian setiap kekurangan cairan. Zat vasoaktif dapat saja diperlukan untuk membantu restorasi cairan. Faktor utama yang terpenting pada tata laksana infeksi abdominal adalah ${ }^{4,9,10}$ diagnosis yang cepat dan tepat, resusitasi yang adekuat, inisiasi terapi 
antibiotik yang tepat, source control yang cepat dan tepat, rumatan nutrisi, dan penilaian ulang respons klinik serta strategi tata laksana yang tepat.

Sebagai pedoman umum dianjurkan untuk mencapai beberapa parameter: (1) central venous pressure (CVP) dan pulmonary occlusion pressure (POP) di antara 8 dan 12 mmHg; (2) mean arterial pressure (MAP) lebih dari $65 \mathrm{mmHg}$; (3) produksi urine lebih dari $0,5 \mathrm{~mL} / \mathrm{kg} / \mathrm{jam}$; dan (4) a mixed venous $\mathrm{O}_{2}$ saturation lebih dari $70 \%$. Koreksi status hemodinamik dan respirasi untuk mencapai target parameter sebaiknya dalam 6 jam pada perawatan ICU. Volume sirkulasi efektif dan tunjangan inotropik/vasopresor dukungan biasanya diperlukan. Dobutamin dapat digunakan dan haemoglobin target sebaiknya di atas $7 \mathrm{~g} / \mathrm{dL}$. Transfusi packed red cells (PRC) diberikan bila perdarahan aktif atau mixed oxygen saturation kurang dari $70 \%$ dan $\mathrm{Hb}$ kurang dari 7. Pada 1 jam pertama pasien umumnya memerlukan 3-6 liter bergantung pada status pasien dan derajat penyakit. Kadar glukosa darah juga harus dipantau ketat dan dipelihara pada kisaran 220 mg/dL. Seluruh pasien sebaiknya diberikan omeprazol untuk pencegahan stress ulcer dan heparin subkutan untuk pencegahan penyakit tromboembolik jika tidak ada temuan koagulopati. Nutrisi enteral sebaiknya secepat-cepatnya diberikan. Penggunaan steroid dosis rendah selama 7 hari diindikasikan pada status syok persisten meskipun resusitasi telah adekuat, atau respons yang buruk terhadap vasopresor atau insufisiensi adrenal. ${ }^{1,7,9,10}$

Penilaian awal respirasi pasien ini di ICU adalah syok sepsis yang mengakibatkan delivery oksigen ke seluruh jaringan termasuk jaringan alveolus paru tidak sampai optimal (secara mikro mengalami hipoksia). Begitu juga dengan jaringan otot otot pernapasan juga tidak mendapatkan asupan oksigen yang optimal dan sentral drive respirasiekspirasi juga terganggu sehingga terjadi gagal oksigenasi dan ventilasi. Hipoksia pada kasus ini dapat diakibatkan oleh hambatan difusi akibat cairan (udema paru minimal), atau kerusakan mikrojaringan alveolar. $\mathrm{AaDO}_{2}$ pasien ini ada perbaikan dari 203 menjadi 154 yang menunjukkan perbaikan dari gangguan difusi. Pada pasien ini dilakukan manipulasi meningkatkan PEEP dari 5 menjadi 8. Dalam perjalanan waktu $\mathrm{P} / \mathrm{F}$ ratio pasien semakin meningkat $>300.6,7,12$

Terapi ventilasi mekanik dilakukan dengan strategi proteksi paru untuk memperbaiki oksigenasi, ventilasi, serta mengurangi kebutuhan oksigen pasien (termasuk menghindari kelelahan otot pernapasan) telah dilakukan pada pasien ini hingga hari terakhir perawatan ICU dengan capaian oksigenasi arteri, ventilasi, dan shunting $\left(\mathrm{PaO}_{2}, \mathrm{PaCO}_{2}\right.$, $\mathrm{SaO}_{2}$, dan $\mathrm{P} / \mathrm{F}$ ratio) dalam batas normal. Akhirnya, pada hari ke-3 di ICU weaning dan deliberation ventilator berhasil dilakukan. ${ }^{13}$

Upaya resusitasi cairan dan penggunaan vasopresor (norepinefrin, dobutamin) dilakukan untuk mencapai MAP >65 mmHg. Penilaian CO, SV, SVR dilakukan dengan menggunakan alat ICON pada hari pertama perawatan dan menunjukkan hasil yang cukup baik setelah terapi. Penilaian $\mathrm{DO}_{2}$ yang mencakup kadar $\mathrm{Hb}$ yang meskipun dalam status anemia, namun mencapai target $\mathrm{CHb}$ $>7 \mathrm{~g} / \mathrm{dL}$ ) selama perawatan. Penilaian $\mathrm{VO}_{2}$ dengan mengukur $\mathrm{ScvO}_{2}$ diperoleh lebih dari $70 \%$ selama perawatan. Nilai yang rendah di awal perawatan menunjukkan jaringan mengekstraksi oksigen dalam jumlah lebih kecil dari dalam darah yang terjadi akibat $\mathrm{DO}_{2}$ tidak adekuat dalam memenuhi $\mathrm{VO}_{2}$. Ini dapat terjadi karena telah memasuki tahap $\mathrm{DO}_{2}$ kritis untuk memenuhi $\mathrm{VO}_{2}$ jaringan yang sangat tinggi. $\mathrm{DO}_{2}$ yang tidak adekuat kemungkinan besar akibat anemia dan masih dalam topangan vasopresor dan inotropik. Curah jantung yang tidak adekuat dapat ditemukan pada syok sepsis akibat komplikasi syok berupa depresi miokardium yang memang sering ditemukan pada kasus syok sepsis. Ketidakseimbangan $\mathrm{DO}_{2}$ dan $\mathrm{VO}_{2}$ ini lah yang berakibat hipoksia jaringan yang dapat dilihat dengan peningkatan kadar laktat pada kasus ini pada hari awal masuk ICU. ${ }^{2,5,14}$

Pada pasien ini ditemukan AKI (acute kidney injury) selama perawatan di ICU, dan termasuk kriteria RIFFLE: Risk, dan AKIN stage 
1 dan Skor KDIGO derajat 1. Karena itu, pasien diberikan terapi farmakologis berupa diuretik furosemid kontinu. Pasien tidak menjalani CRRT dan hemodialisis. ${ }^{15}$

Infeksi pada pasien ini diatasi dengan pemberian dua antibiotik yang sesuai dengan anjuran pada peritonitis sekunder. Terapi antibiotik sebaiknya dimulai secepatcepatnya. Terapi inisial diberikan secara empirik. Pemilihan antibiotik sebaiknya berdasar atas mikro-organisme yang dicurigai dan kapasitas antibiotik untuk mencapai kadar yang adekuat dalam kavitas peritoneum. Perforasi pada saluran cerna bagian atas umumnya berhubungan dengan bakteri grampositif, yang sensitif terhadap cephalosporin dan penicillin. Perforasi usus halus distal dan colon umumnya diserang polimikrob aerobik dan anaerobik. Terapi kombinasi sebaiknya dipandu dengan antibiogram ICU/ rumah sakit. Lini pertama terapi biasanya berbeda pada tiap-tiap institusi, dan dapat saja melibatkan medikasi anti-anaerobik seperti metronidazol atau klindamisin, yang dikombinasi dengan aminoglikosid (gentamisin atau amikasin) pada kasus tertentu, ciprofloxacyn dan cephalosporins generasi ketiga atau keempat (ceftriaxone atau cefotaxime). Pada kasus berat dan pada pasien dengan risiko tinggi infeksi nosokomial, beberapa penulis menyarankan monotorapi inisial dengan piperacillin-tazobactam, atau carbapenem (imipenem atau meropenem). Sebagai alternatif dapat cephalosporin generasi keempat dan metronidazole. Dosis yang diberikan harus sangat hati-hati karena beberapa pasien dalam kondisi volume distribusi yang tidak tetap (akibat pergeseran cairan yang bermakna). Durasi terapi sebaik disesuaikan dengan temuan saat pembedahan. Tidak ditemukannya demam, peningkatan atau pergeseran ke kiri hitung leukosit, dapat menjadi penanda dalam menghentikan terapi antibiotik karena insidensi rekurensi biasanya rendah bila parameter tersebut telah tercapai. Jika leukosit dan suhu rektal ditemukan normal selama 48 jam, antibiotik dapat dihentikan pada hari ke-4 pascabedah, bergantung pada patologi peritonitis..$^{710,16,17}$
Pada pasien ini didapatkan syok septik dengan komplikasi AKI dan sudah terjadi overload cairan karena balans kumulatif positif dengan gejala klinis edema anasarka. KDIGO mendefinisikan AKI sebagai peningkatan $\mathrm{SCr}$ $0,3 \mathrm{mg} / \mathrm{dL}$ dalam 48 jam atau peningkatan $\mathrm{SCr}$ sebanyak 50\% selama 7 hari terakhir. Sistem ini mirip dengan AKIN; namun GFR kurang dari $35 \mathrm{~mL} /$ menit/1,73 $\mathrm{m}^{2}$ ditambahkan untuk pasien pediatrik untuk menentukan AKI derajat $3 .^{10,16,18}$

Pasien mengalami second hit injury dan sudah terjadi disfungsi organ serta diperberat dengan kondisi hipoalbumin, sehingga kecukupan cairan intravaskular harus dinilai dengantepat.Pemberiancairanyangberlebihan akan memperparah komplikasi kondisi pasien yang sudah dengan edema anasarka, bahkan meningkatkan risiko kematian. Untuk kecukupan cairan intravaskular pada kasus ini dinilai dengan menggunakan IVC collapsibility index dan pengukuran $\mathrm{CO}, \mathrm{CI}$ menggunakan alat ICON. Selain itu, juga dilakukan penilaian perfusi jaringan dengan capillary refill dan pemeriksaan laktat. Dalam penilaian kecukupan cairan intravaskular didapatkan bahwa pasien sudah cukup cairan dan menuju tahap optimalisasi dan stabilisasi. Evakuasi (deresusitasi) kemudian dilakukan setelah melalui penilaian dan pemeriksaan sesuai dengan konsep ROSE (resusitation, optimalization, stabilization, evacuation). ${ }^{19}$

Diuretik atau kombinasi dengan albumin untuk mengeluarkan cairan yang balans positif setelah resusitasi pada pasien dengan hemodinamik yang stabil. Penelitian lain menyatakan bahwa penarikan cairan seringkali dimulai pada fase stabilisasi atau deeskalasi setelah resusitasi pada pasien yang berisiko akumulasi cairan berlebih. Penting melakukan manajemen pemberian cairan yang hati-hati dengan mengurangi cairan yang tidak penting (tidak esensial) pada pasien dengan hemodinamik stabil (misalnya topangan vasoaktif semakin berkurang) dan target resusitasi tercapai lebih dapat mentoleransi tindakan penarikan cairan yang aktif. Diuretik telah lama menjadi terapi utama dalam mencegah dan sebagai terapi AKI. 
Overload volume sering terjadi dan diuretik memfasilitasi manajemen untuk kasus seperti ini. Beberapa penelitian menunjukkan bahwa furosemid menurunkan $\mathrm{O}_{2}$ demand dan memperbaiki klirens debris nekrotik. Penelitian menunjukkan bahwa furosemid tidak menurunkan kebutuhan akan RRT atau menurunkan mortalitas bila diterapkan untuk terapi AKI. Loop diuretik direkomendasikan untuk terapi volume overload dan hiperkalemia sebagai konsekuensi AKI, namun tidak berperan dalam mencegah atau sebagai terapi AKI. Belum dilaporkan satu vasopresor yang efektif untuk AKI, pemilihan vasopressor didasarkan pada penyebab hipotensi dan hipoperfusi. Jumlah pasien yang selamat yang tidak mengalami AKI dilaporkan hampir sama pada pasien yang menerima vasopresin dan norepinfrin. Namun demikian, lebih banyak pasien yang memerlukan RRT pada pasien yang menerima vasopresin. ${ }^{5,6,19}$

KDIGO menganjurkan total energi harian sebaiknya 20-30 kcal/kgBB/hari dengan karbohidrat 3-5 g/kgBB/hari dan lemak 0,8-1 $\mathrm{g} / \mathrm{kgBB} /$ hari pada semua derajat AKI. Protein yang dianjurkan adalah 0,8-1,0 g/kgBB/hari pada pasien non-katabolik dengan AKI yang menerima dialisis, $1,0-1,5 \mathrm{~g} / \mathrm{kgBB} /$ hari pada pasien AKI yang menerima RRT dan 1,7 g/ $\mathrm{kgBB} /$ hari pada pasien yang menerima CRRT dan pada pasien hiperkatabolik. ${ }^{20}$

\section{Simpulan}

Penatalaksanaan peritonitis sekunder dengan komplikasi sepsis dan AKI telah berhasil dialakukan di ICU dengan menerapkan strategi proteksi paru melalui ventilator, topangan kardiovaskular, diuretik, dan antibiotik spektrum luas. Peritonitis sekunder memiliki tingkat mortalitas yang cukup tinggi, namun dengan source control yang adekuat dan manajemen di ICU yang agresif maka diperoleh hasil yang baik seperti pada kasus ini. Target makrodinamik dan mikrodinamik merupakan panduan tujuan terapi yang dilakukan. Ventilator dengan target perbaikan oksigenasi dan ventilasi pasien, topangan obat vasopresor, dan inotropik dini diberikan jika resusitasi telah diberikan, tetapi target makrodinamik dan mikrodinamik belum tercapai. Terapi fluid overload, diuretik masih menjadi pilihan utama. Terapi antibiotik yang tepat sasaran serta pemberian nutrisi yang sesuai sangat menentukan keberhasilan terapi.

\section{Daftar Pustaka}

1. Xu Z, Cheng B, Fu S, Liu X, Xie G, Li Z, dkk. Coagulative biomarker on admission to the ICU predict acute kidney injury and mortality in patients with septic shock caused by intra-abdominal infection. Infect Drug Resist. 2019;12:2755-64.

2. Kopitko C, Medve L, Gondos T. The value of combined hemodynamic, respiratory and intra-abdominal pressure monitoring in predicting acute kidney injury after major intraabdominal surgeries. Ren Fail. 2019;41(1):150-8.

3. Mureșan MG, Balmoș IA, Badea I, Santini A. Abdominal sepsis: an update. J Crit Care Med. 2018;4(4):120-5.

4. Dugar S, Chaudhary C, Duggal A. Sepsis and septic shock: guideline-based management. Cleveland Clin J Med. 2020;87(1):53-61.

5. Gyawali B, Ramakrishna K, Dhamon AS. Sepsis: the evolution in definition, pathophysiology, and management. SAGE Open Med. 2019;7:1-13.

6. Peerapornratana $S$, Caballero CL, Gomes $\mathrm{H}$, Kellum JA. Acute kidney injury from sepsis: current concepts, epidemiology, pathophysiology, prevention and treatment. Kidney Int. 2019;96(5):108399.

7. Montomoli J, Donati A, Ince C. Acute kidney injury and fluid resuscitation in septic patients: are we protecting the kidney?. Nephron. 2019;143:170-3.

8. Olesen MW, Moller MH, Johansen KK, Aasvang EK. Effects of post-operative furosemide in adult surgical patients: a systematic review and meta-analysis of randomised clinical trials. Acta Anaesthesiol Scand. 2020;64:282-91. 
9. Steinbach CL, Topper C, Adam T, Kees MG. Spectrum adequacy of antibiotic regimens for secondary peritonitis: a retrospective analysis in intermediate and intensive care unit patients. Ann Clin Microbiol Antimicrob. 2015;14:48.

10. Montravers P, Dufour G, Guglielminot J. Dynamic changes of microbial flora and therapeutic consequences in persistent peritonits. Crit Care. 2015;19:7.

11. Waele JJ, Tellado JM, Weiss G, Alder J, Kruesmann F, Arvis P, Hussain T, dkk. Efficacy and safety of moxifloxacin in hospitalized patients with secondary peritonitis: pooled analysis of four randomized phase III trials. Surg Infect. 2014;15:567-75.

12. Augustin P, Dinh AT, Valin N, Desmard M, Crevecoeur MA, Muller C, dkk. Pseudomonas aeruginosa post-operative peritonitis: clinical features, risk factors, and prognosis. Surg Infect. 2013;14:297303.

13. Mazuski JE, Tessier JM, May AK, Sawyer RG, Nadler EP, Rosengart MR, dkk. The surgical infection society revised guidelines on the management of intra-abdominal infection. Surg Infect. 2017;18(1):1-76.
14. Singer M, Deutschman CS, Seymour CW, Shankar M, Annane D, Bauer M, dkk. The third international consensus definitions for sepsis and septic shock (Sepsis-3). JAMA. 2016;315:801-10.

15. Divatia JV, Amin PR, Ramakrishnan N, Kapadia FN, Todi S, Sahu S, dkk. Intensive care in India: The Indian intensive care case mix and practice patterns study. Indian J Crit Care Med. 2016;20:216-25.

16. Simpson SQ. New sepsis criteria: a change we should not make. Chest. 2016;149:1117-8.

17. Angus DC, van der Poll T. Severe sepsis and septic shock. N Engl J Med. 2013:369 (21):2063.

18. Poston JT, Koyner JL. Sepsis associated acute kidney injury. BMJ. 2019;364:k4891.

19. KDIGO Kidney Disease: Improving global outcomes (KDIGO) acute kidney injury work group. KDIGO Clinical Practice Guideline for Acute Kidney Injury. Kidney Int Suppl. 2012;2(1):1-138.

20. Kellum JA, Lameire N. KDIGO AKI guideline work group diagnosis, evaluation, and management of acute kidney injury: a KDIGO summary. Crit Care. 2013;17:204. 